A C T A C H.E M I C A S C A N D I N A V I C A 4 (1950) $675-687$

\title{
Studies on N-Substituted Barbituric Acid Derivatives. II
}

\author{
OLOV ROSEN and FINN SANDBERG
}

Department of Organic Chemistry, Kungl. Farmaceutiska Institutet, Stockholm, Sweden

Tn Part I of this paper, the syntheses and chemical properties of series of I-carbethoxymethyl-barbituric acid derivatives, which are mono-alkyl or nonsubstituted in the 5-position, are reported. Part II deals with those barbiturates of this type which are di-alkyl substituted in the 5,5-position.

Reaction 2

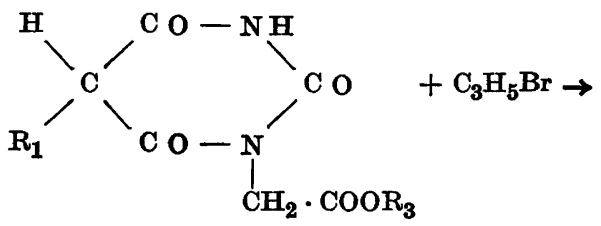

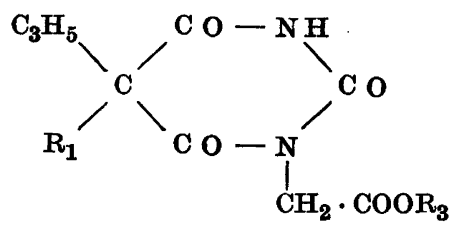

where: $\mathbf{R}_{1}=\mathrm{H}$, or alkyl radicals with 1 to $5 \mathrm{C}$-atoms, $R_{3}=$ alkyl radicals with 1 to 3 C-atoms, mentioned in the introduction to Part $I$ of this paper, was carried out in two modifications as follows:

For the synthesis of the substances $21-29$ and 31 in Table 3 the method described in D. R. P. 526854 was applied.

As an example of this method, the synthesis of derivative 24, 1-carbethoxymethyl-5-isopropyl-5-allyl-barbituric acid, is described.

$25.6 \mathrm{~g}$ of 1-carbethoxymethyl-5-isopropyl-barbituric acid (9) was dissolved in $101 \mathrm{ml}$ of $1 \mathrm{~N}$ sodium hydroxide solution, and $0.75 \mathrm{~g}$ of copper sulphate and allyl bromide $(12.7 \mathrm{~g})$, in slight excess of the theoretical amount, were added. The reaction mixture was shaken for 2 hours at room temperature. An oil separated, which solidified on standing overnight. The crude product, bluegreen in colour, was sucked off and dissolved in alcohol. On passing hydrogen sulphide through the solution, copper sulphide precipitated. This was filtered off. The filtrate was diluted with water and clarified with charcoal. Recrystal- 
lization from aqueous alcohol gave the pure substance $24\left(\mathrm{~m} . \mathrm{p} .75^{\circ}\right)$ in a yield of 62 per cent.

A few noteworthy features of these syntheses may be mentioned.

The crystallization of the higher homologues presented considerable difficulties, but was accomplished except for the $n$-hexyl-allyl derivative.

In the synthesis of derivative 31, 1-carbethoxymethyl-5,5-diallyl-barbituric acid, especially when the shaking-time was prolonged to $3-3 \frac{1}{2}$ hours or an excess of sodium hydroxide solution was used for the dissolving of 1 carbethoxymethylbarbituric acid (2), only a good yield of 1-carboxymethyl5,5-diallyl-barbituric acid (37) was obtained at times. This substance is a dibasic acid which could, however, be titrated as a monobasic acid using methylred as an indicator. When using phenolphthalein, the end-point of the titration was not sharp. Found: equiv. wt. 267.1; C 54.6; H 5.38; $\mathrm{N} 10.3$ per cent; $\mathrm{C}_{12} \mathrm{H}_{14} \mathrm{O}_{5} \mathrm{~N}_{2}$ requires: equiv. wt. 266.2; $\mathrm{C} 54.1 ; \mathrm{H} 5.30 ; \mathrm{N} 10.5$ per cent. M. $\mathrm{p}$. $167-168^{\circ}$. It is therefore apparent that in this case the following hydrolysis had occurred:

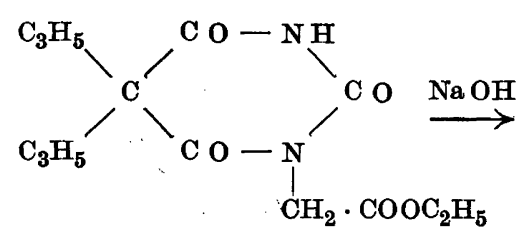

(31)<smiles>CCCCCC(C)(CO)CCCC</smiles>

(37)

As mentioned in Part I of this paper, no allyl derivative could be formed from 1-carbethoxymethyl-5-acetyl-barbituric acid (16). This applied both when the reaction took place at room temperature and when the reaction mixture, with shaking, was heated in a bomb tube at $95^{\circ} \mathrm{C}$ for $2-3$ hours.

The other modification of reaction 2, used for the synthesis of compounds $30-33$ in Table 3, is an application of a method outlined in D. R. P. 268158. According to this method, substance 31, 1-carbethoxymethyl-5,5-diallylbarbituric acid, was prepared as follows:

A solution of $53.5 \mathrm{~g}$ of 1-carbethoxymethyl-barbituric acid (2) in a mixture of $250 \mathrm{~g}$ of alcohol and $125 \mathrm{~g}$ of water was refluxed for two hours with a mixture of $61.5 \mathrm{~g}$ of allyl bromide and $68 \mathrm{~g}$ of sodium acetate in $125 \mathrm{~g}$ of water and $310 \mathrm{~g}$ of alcohol. The alcohol was distilled off under reduced pressure and a brown semisolid mass separated which, after filtering, solidified on washing with water. The crude product (93 per cent of the theoretical yield) was dissolved in aqueous alcohol, and the alcoholic solution was partially decolourized with charcoal. On diluting with water an oil again separated, which 
was dissolved in $5 N$ sodium hydroxide solution; the alkaline solution being diluted with water. By careful addition of $5 N$ hydrochloric acid to about pH 7, the pure compound 31 crystallized on standing overnight. On further addition of hydrochloric acid, the oily mono-allyl derivative (18) formed.

The propyl- and butyl-homologues (32 and 33) occurred as viscous oils, which failed to crystallize even after repeated precipitation with hydrochloric acid from their alkaline aqueous solutions. However, the determination of the

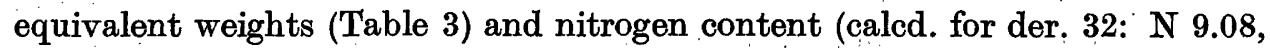
found: $\mathrm{N} 8.65$ per cent and calcd. for der. 33: $\mathrm{N} 8.68$, found 8.29 per cent) indicated that the products obtained were not pure.

Table 3.

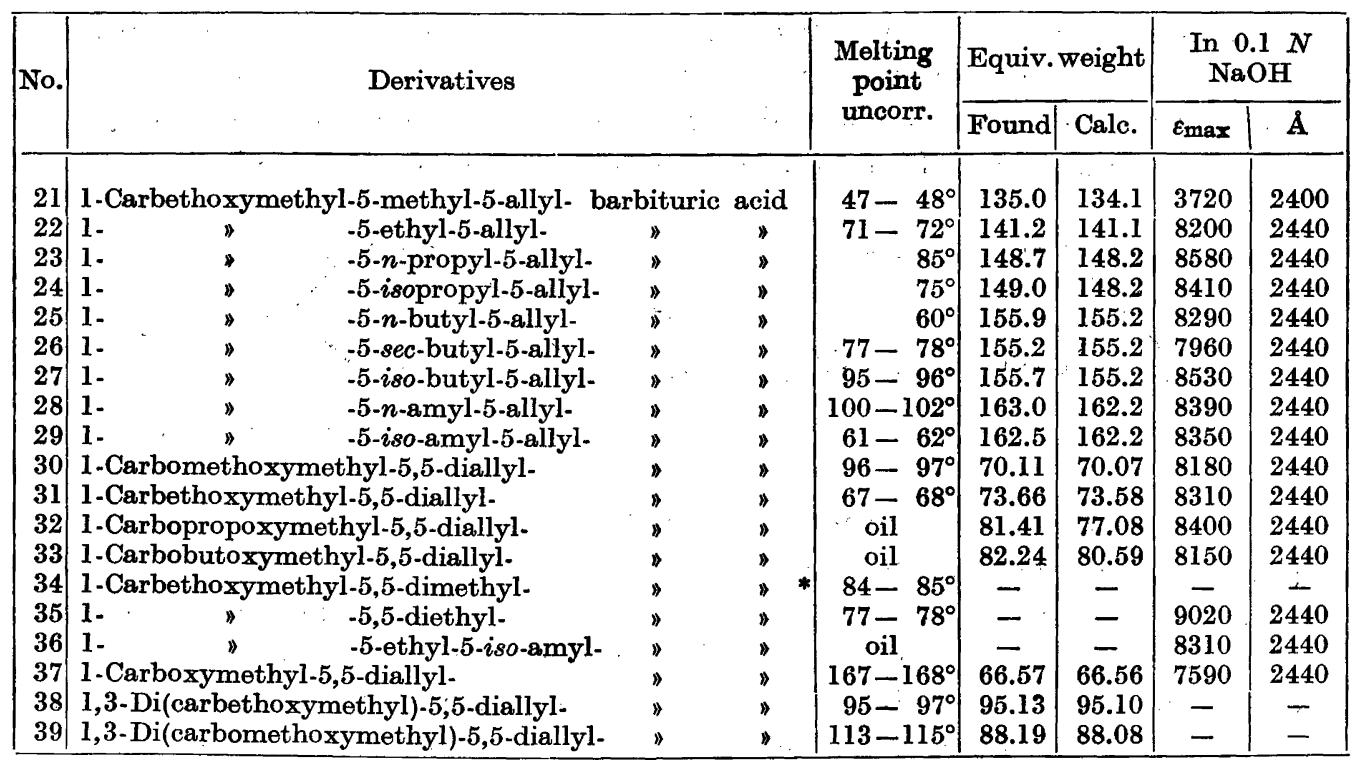

* This substance is described by Rosén ${ }^{1}$.

On further acidification of the solutions of derivatives $30-33$, after removal of the oils, the corresponding carbonic acid derivative, 1-carboxymethyl-5,5diallyl-barbituric acid (37) precipitated.

The identity of the compounds $21-33$ was established by the method of synthesis, found to be reliable, and by the determination of the equivalent weights (see Table 3). The bromometric method of the Swedish Pharmacopeia Ed. XI for the assay of allyl group in Allypropymalum and Diallymalum was used for this purpose. Good results were obtained for derivatives $21-29$, 
containing one allyl group. On the other hand, the bromine addition was not complete in substances $30-33$ and $37-39$ with two allyl groups, and this method gave too high values even when using a reaction time of several hours. Neither did the method described by Schill ${ }^{2}$ give correct analytical figures.

The following method, proposed by Schill, however, gave figures in close agreement with those required theoretically:

To a solution containing $0.1000-0.1500 \mathrm{~g}$ of the barbiturate in $15 \mathrm{ml}$ of methanol (analytically pure, acetone-free) in a $300 \mathrm{ml}$ glass-stoppered flask, $25 \mathrm{ml}$ of $0.1 \mathrm{~N}$ potassium bromate and $5 \mathrm{~g}$ of potassium bromide were added. When the bromide was dissolved, $10 \mathrm{ml}$ of $2 \mathrm{~N}$ sulphuric acid were added and the solution was allowed to stand for 5 minutes. After the addition of $1 \mathrm{~g}$ of potassium iodide, the liberated iodine was titrated with $0.1 \mathrm{~N}$ sodium thiosulphate using starch as an indicator. When approaching the end-point of the titration, $5 \mathrm{ml}$ of chloroform were added to dissolve the precipitate of the bromination product. A blank determination was made simultaneously.

Derivatives 35 and 36 were prepared according to reaction 3:<smiles>[Y11]C(=O)CC(=O)OCC</smiles>

wherein $\mathrm{R}_{1}=$ alkyl radical with 1 to $5 \mathrm{C}$-atoms, (mentioned in the introduction to Part I of this paper).

1-Carbethoxymethyl-5,5-diethyl-barbituric acid (35). $39 \mathrm{~g}$ of diethyl-malonyl chloride, obtained by the method of Fischer and Dilthey ${ }^{3}$, was mixed with $64 \mathrm{~g}$ of hydantoic acid ethyl ester and heated on a water-bath for 20 hours. After cooling and addition of water, the aqueous solution was extracted with ether. On distilling the solvent, the ether extract left an oily residue, which was dissolved in $1 N$ sodium hydroxide solution. A precipitate appeared on the addition of hydrochloric acid to the filtrate. Recrystallization of this fraction by reprecipitation with hydrochloric acid from its alkaline aqueous solution gave the pure substance, m. p. $77-78^{\circ} \mathrm{C}$. Found: C 53.4; H 6.57; $\mathrm{N} 10.29$ per cent; $\mathrm{C}_{12} \mathrm{H}_{18} \mathrm{O}_{5} \mathrm{~N}_{2}$ requires: $\mathrm{C} 53.3 ; \mathrm{H} 6.72 ; \mathrm{N} 10.37$ per cent.

1-Carbethoxymethyl-5-ethyl-5-isoamyl-barbituric acid (36). $35 \mathrm{~g}$ of ethylisoamyl malonyl chloride (b. p. $225-235^{\circ} \mathrm{C}$ ) was prepared from ethyl-isoamyl malonic acid $(52 \mathrm{~g})$ and phosphorus pentachloride ( $148 \mathrm{~g}$ ) according to the procedure of Fleischer and Siefert ${ }^{4}$. Ethyl-isoamyl malonyl chloride $(35 \mathrm{~g})$ and hydantoic ethyl ester ( $48 \mathrm{~g}$ ) were mixed and heated on a water-bath for 
20 hours. The mixture, after cooling, was then poured into water $(70 \mathrm{ml})$, the aqueous solution being extracted with ether. On removal of the ether and cooling, an oil (40 g) remained. The oily product distilled at $187^{\circ}$ to $189^{\circ} \mathrm{C}$ under $13 \mathrm{~mm} \mathrm{Hg}$ pressure as a colourless oil which did not solidify on standing.

- Found: $\mathrm{N} 8.69$ per cent; $\mathrm{C}_{15} \mathrm{H}_{24} \mathrm{O}_{5} \mathrm{~N}_{2}$ requires: $\mathrm{N} 8.97$ per cent.

The following method of synthesis was found usable for obtaining a barbiturate with the carbethoxymethyl-group both in the 1-position and in the 3-position.

1,3-Di (carbethoxymethyl)-5,5-diallyl-barbituric acid (38). To a solution of $4.6 \mathrm{~g}$ of sodium $(0.2 \mathrm{~mole})$ in $200 \mathrm{ml}$ of alcohol, $20.8 \mathrm{~g}$ of 5,5-diallyl-barbituric acid $(0.1 \mathrm{~mole})$ and $24.5 \mathrm{~g}$ of ethyl chloroacetate $(0.2 \mathrm{~mole})$ were added. The mixture was refluxed on a water-bath for three hours. Sodium chloride precipitated during the refluxing time. After heating it was sucked off.- The filtrate was concentrated to about $100 \mathrm{ml}$ by distilling off the alcohol. An oil, which hardened on standing, separated on acidification with $5 \mathrm{~N}$ hydrochloric acid. This product was partly soluble in $2 N$ sodium hydroxide solution. The pure substance 38 was obtained from the insoluble part (11.5 g) by recrystallization from aqueous alcohol. Table 3 gives the melting point and equivalent weight.

The compounds 1-carbethoxymethyl-5,5-diallyl-barbituric acid (31), 1 carboxymethyl-5,5-diallyl-barbituric acid (37), and unchanged 5,5-diallylbarbituric acid were isolated from the alkaline solution.

Using molar equivalents of sodium, 5,5-diallyl-barbituric acid and ethyl chloroacetate, the same compounds were formed, but the yield of derivative 38 was decreased to $10.2 \mathrm{~g}$ (from $11.5 \mathrm{~g}$ ). Found: $\mathrm{N} 7.42$ per cent (Dumas): $\mathrm{C}_{18} \mathrm{H}_{24} \mathrm{O}_{7} \mathrm{~N}_{2}$ requires: $\mathrm{N} 7.37$ per cent.

1,3-Di (carbomethoxymethyl)-5,5-diallyl-barbituric acid (39) was obtained in a yield of $13.9 \mathrm{~g}$ from $4.6 \mathrm{~g}$ of sodium $(0.2 \mathrm{~mole}), 200 \mathrm{ml}$ of methanol, $41.6 \mathrm{~g}$ of 5,5-diallyl-barbituric acid (0.2 mole) and $21.7 \mathrm{~g}$ of methyl chloroacetate $(0.2 \mathrm{~mole})$ in an analogous way as described above for derivative 38 .

In this case, 1-carbomethoxymethyl-5,5-diallyl-barbituric acid (30), 1carboxymethyl-5,5-diallyl-barbituric acid (37), and unchanged 5,5-diallylbarbituric acid were isolated from the alkaline solution.

Derivative 39 is remarkably less soluble in ethanol than substance 38 and its melting point and equivalent weight are given in Table 3. Found: $\mathrm{N} 7.98$ per cent (Dumas); $\mathrm{C}_{16} \mathrm{H}_{20} \mathrm{O}_{7} \mathrm{~N}_{2}$ requires: $\mathrm{N} 7.95$ per cent.

A number of sodium salts (Table 4) were prepared as follows: The acids were dissolved in equivalent amounts of $0.8 \mathrm{~N}$ alcoholic sodium hydroxide solution. By the addition of a conciderable excess of ether the solutions became turbid. On standing overnight in a stoppered flask the sodium salts 
crystallized. Yield $74-83$ per cent. Their equivalent weights were determined by titration with $0.1 N$ hydrochloric acid using methyl red as an indicator. Potassium salts (Table 4) were prepared in an analogous way.

Table 4.

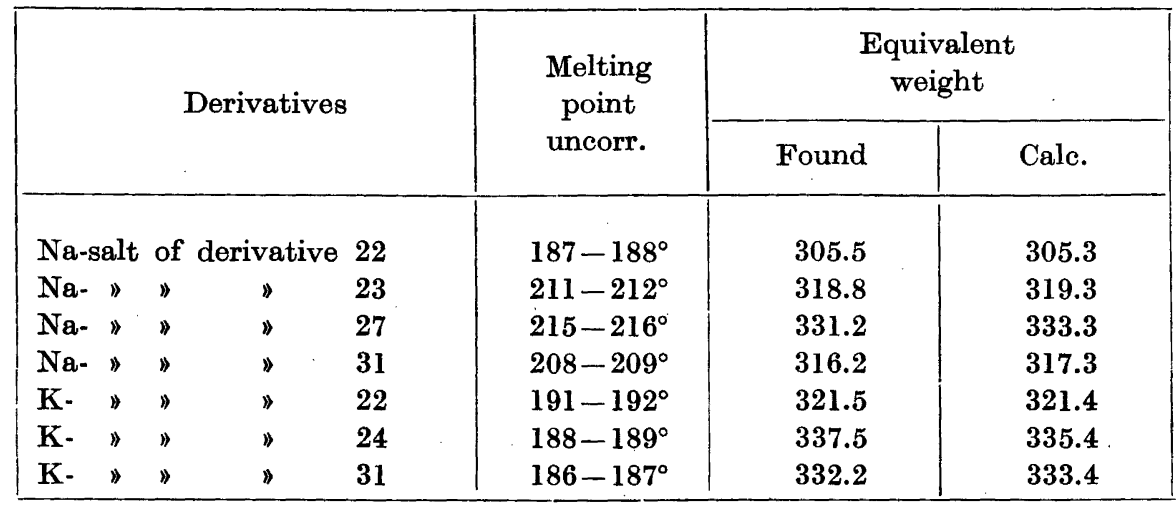

The stability of the aqueous solutions of these salts on storage is comparatively poor. Thus, the 10 per cent solution of the sodium salt of derivative 31 , stored at room temperature for 8 days, showed some 50 per cent decomposition, ascertained by the ultra-violet absorption method (see the following). During the storage, the $\mathrm{pH}$ of the solution decreased from 9.45 to 9.21 and a precipitation of the acid (derivative 31) occurred.

Heating of the aqueous solutions caused rapid degradation, and it was not therefore possible to sterilize the solutions by heat.

Stable, concentrated (about 20 per cent) solutions of compounds $21-36$ for pharmaceutical purposes were obtained by use of the following solvents:

diethylamine and alcohol $(1+1)$

triethanolamine and alcohol $(10+3)$

methylacetamide and water $(7+3)$.

Xanthydrol is used for identifying barbituric acid derivatives [Fabre ${ }^{5}$, Jespersen and Thoudahl-Larsen ${ }^{6}$, Gad 7, McCutcheon and Plein ${ }^{8}$ ], but the $\mathrm{N}$-substituted barbiturates included in this paper did not react with xanthydrol in glacial acetic acid solution. This is in agreement with the findings of McCutcheon and Plein ${ }^{8}$, who failed to obtain any xanthyl derivative with the $\mathrm{N}$-substituted barbiturates Evipal and Mebaral, which have a methyl group on the nitrogen.

The pharmacological properties of substances $21-27,29,31$ and 35 are described by Sandberg ${ }^{9}$, and those of the others will be reported later. 
The alkaline hydrolysis was studied and the following scheme may be given:<smiles>[R16]OC(=O)N(C)ONC(=O)OC([R12])([R12])C</smiles>

A<smiles>[R1]C([R12])([R2])C(=O)NC(=O)NCC(=O)O</smiles>

C<smiles>[R1]C1([R1])CONC(=O)N(CC(=O)O)O1</smiles>

B

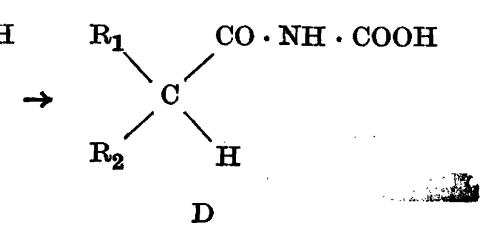

A represents the compounds 1-36. 1-carboxymethyl-5,5-diallyl-barbituric acid (37), belonging to type $B$, was isolated from the syntheses of substances $30-33$, as described above.

2-Methyl-valeryl-hydantoic acid, $\quad \mathrm{CH}_{3} \mathrm{CH}_{2} \mathrm{CH} \cdot \mathrm{CH}_{2} \mathrm{CO} \cdot \mathrm{NH} \cdot \mathrm{CO} \cdot \mathrm{NH} \cdot$ $\mathrm{CH}_{3}$

$\mathrm{CH}_{2} \mathrm{COOH}$, of type $\mathrm{C}$, was isolated by hydrolysis of derivative 11, 1-carbethoxymethyl-5-sec-butyl-barbituric acid. The equivalent weight was determined by titration with $0.1 \mathrm{~N}$ sodium hydroxide solution using phenolphtalein as an indicator. Found: equiv. wt. 215.2 and N 12.75 per cent; $\mathrm{C}_{9} \mathrm{H}_{16} \mathrm{O}_{4} \mathrm{~N}_{2}$ requires: equiv. wt. 216.2 and $\mathrm{N} 12.95$ per cent. M. p. $215-216^{\circ} \mathrm{C}$.

By hydrolysis of 1-carbethoxymethyl-5- $n$-butyl-barbituric acid (10), a substance of type D was isolated, namely: caproylcarbamic acid, $\mathrm{CH}_{3} \mathrm{CH}_{2}-$ $\mathrm{CH}_{2} \mathrm{CH}_{2} \mathrm{CH}_{2} \mathrm{CO}$. $\mathrm{NH}$. $\mathrm{COOH}$ with melting point $80-81^{\circ} \mathrm{C}$. Its equivalent weight was determined by titration with $0.1 \mathrm{~N}$ sodium hydroxide solution with phenolphtalein as an indicator. Found: equiv. wt. 157.9 and $\mathrm{N} 8.74$ per sent; $\mathrm{C}_{7} \mathrm{H}_{13} \mathrm{O}_{3} \mathrm{~N}$ requires: equiv. wt. 159.2 and $\mathrm{N} 8.80$ per cent.

\section{ULTRA-VIOLET ABSORPTION SPECTRA}

Ultra-violet absorption spectra of the substances prepared were measured with a Beckman quartz spectrophotometer, using $1 \mathrm{~cm}$ silica cells. Molar extinction coefficients, $\varepsilon$, were calculated from the familiar equation $\log$ $I / I=\varepsilon \cdot c \cdot l$, where $I_{0}$ is the intensity of the light passing through the sol- 
vent; $I$ is the intensity of the light passing through the solution; $c$ is the molar concentration and $l$ is the thickness of the cell in centimeters.

Fig. 4 shows the ultra-violet absorption curves for 1-carbethoxymethyl-5,5diallyl-barbituric acid (31) at various hydrogen ion concentrations from $\mathrm{pH}$ 1.1 to $\mathrm{pH}$ 13. The concentration of all solutions is $4.970 \cdot 10^{-5}$ molar. The curve at $\mathrm{pH} 6.8$ shows the superposition of two bands, indicated by the points of inflection. It is evident that the addition of base progressively increases the absorption of radiation at about $2430 \AA$, exhibiting a maximum value of $\varepsilon_{\max }=8600$ at $\mathrm{pH} 10.9$. At $\mathrm{pH} 13$ the absorption is decreased so that $\varepsilon_{\max }=$ 8300 at $2440 \AA$. On the other hand, in acid solution (pH 1.1) the $2430 \AA$ band is quite weak, although there is an absorption peak in the shorter wave length region, $\varepsilon_{\max }$ being 7000 at $2150 \AA$.

In agreement with the results obtained by Fredholm ${ }^{10}$ on the tautomerism of 5,5-diethyl-barbituric acid, the following tautomeric equilibria may occur:

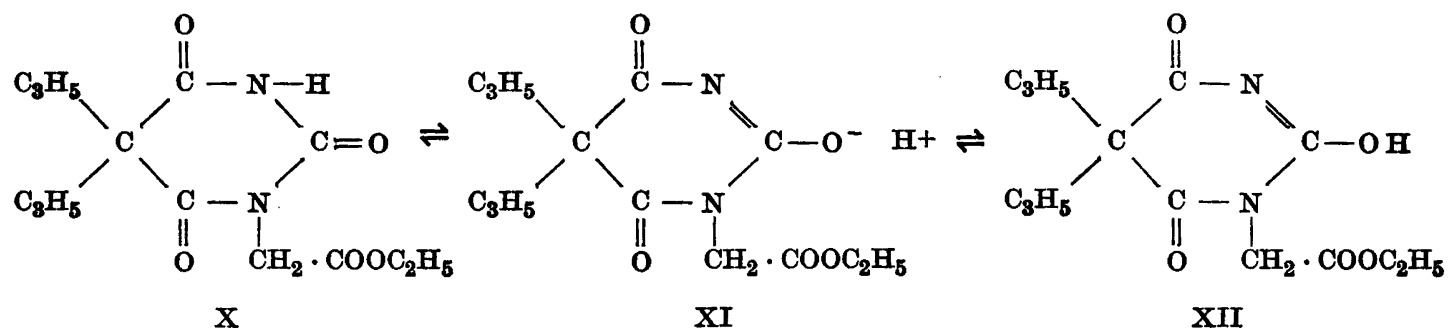

where the keto-form $\mathrm{X}$ predominates in strongly acid solution (the peak at $2150 \AA$ ) and the ion XI in slightly alkaline solution (the peak at $2430 \AA$ ). At pH 13, however, the equilibrium has shifted and the enol-form XII, as the sodium salt, is mainly present. According to this interpretation, the absorption of the undissociated sodium salt is less than that of the ion XI. This phenomenon will be discussed below.

On the other hand, the theory of resonance indicates that resonance may occur between the following ionic forms, in addition to that obtained in the resonance hybride of the carbonyl form $\mathrm{X}$

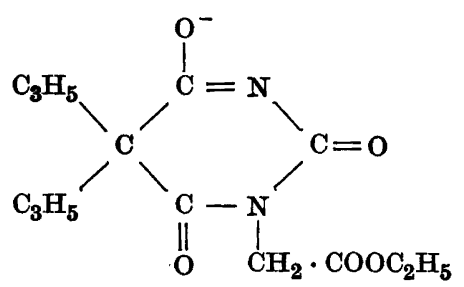

XIII<smiles>CCCCCCC1(c2ccccc2)C(=O)[N-]C(=O)N(CC(=O)OCC)C1=O</smiles>

XIV

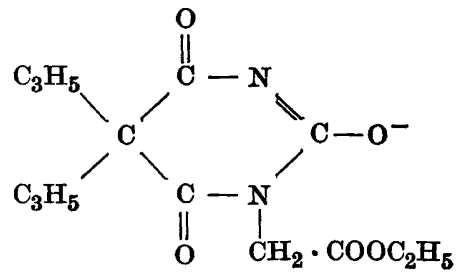

$\mathrm{XI}$ 


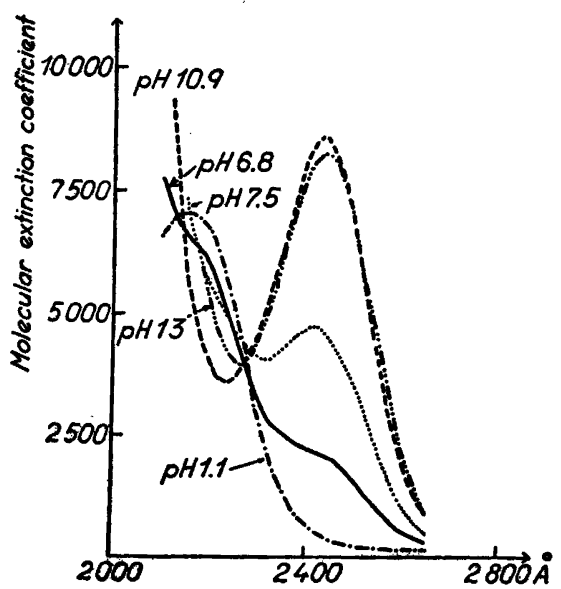

Fig. 4. Absorption spectra of $4.970 \cdot 10^{-5}$ molar aqueous solutions of 1-carbethoxymethyl5.5-diallyl-barbituric acid at various $p H$ values.

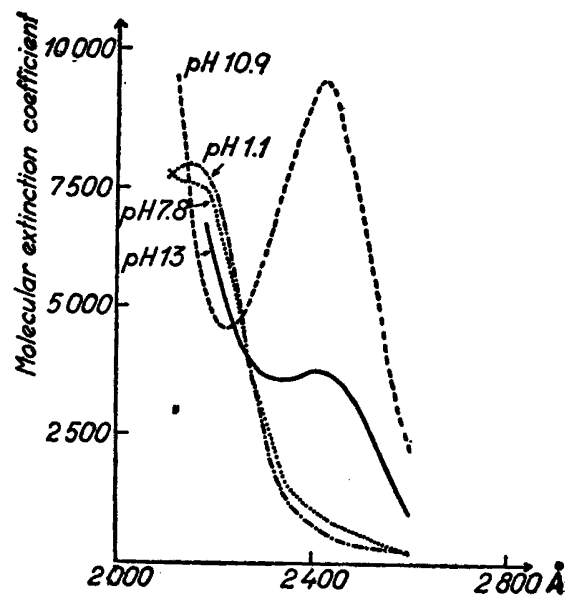

Fig. 5. Absorption spectra of $5.218 \cdot 10^{-5}$ molar aqueous solutions of 1-carbethoxy. methyl-5-methyl-5-allyl-barbituric acid at various $p H$.

From this point of view the absorption peak at $2430 \AA$ may be attributed to the configurations XI, XIII, and XIV (not to any single one of them).

Table 3 gives the wave-lengths and $\varepsilon_{\max }$-values in $0.1 N$ sodium hydroxide solution for the derivatives prepared. It will be seen that all the 1,5,5-trisubstituted barbiturates - with two exceptions (see the following) - have a maximum at $2440 \AA$, the molecular extinction coefficient being generally within the limits 7500 and 9000 . Furthermore, there is no general relation between the substituent group and the magnitude of the molecular extinction coefficient. The relatively high value for the extinction coefficient was employed as the basis of a spectrophotometric method of assay of these barbiturates in different solutions. At $\mathrm{pH} 13$ the barbiturates studied conform to the Lambert-Beer equation.

The two exceptions from the $2440 \AA$ band at $\mathrm{pH} 13$ will now be discussed.

The ultra-violet absorption spectra of 1-carbethoxymethyl-5-methyl-5allyl-barbituric acid (21) as a function of $\mathrm{pH}$ in aqueous $5.218 \cdot 10^{-5}$ molar solutions are illustrated in Fig. 5. The general shape of the curves in Fig. 5 is similar to that in Fig. 4. An important difference is that at $\mathrm{pH} 13$, instead of an expected strong band at $2440 \AA$, there is a band of much reduced intensity at $2400 \AA, \varepsilon_{\max }$ being only 3720 . At pH $10.9, \varepsilon_{\max }$ is 9380 at $2420 \AA$ and at pH 1.1 there is an absorption peak at $2150 \AA\left(\varepsilon_{\max }=7750\right)$. Under these conditions the following tautomerism would seem most likely: 
<smiles>CCCCCCCCC(=O)OCCN1C(=O)NC(=O)C1(C)CCCC</smiles>

$\mathrm{XV}$

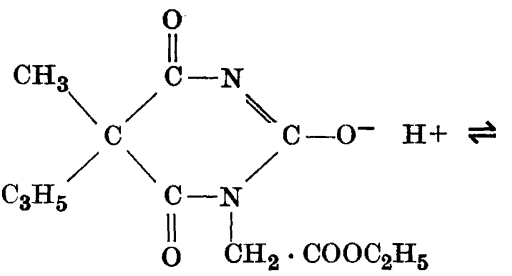

XVI<smiles>CCCCC1(C)C(=O)NN(CC(=O)OCC)C1=O</smiles>

XVII

The absorption spectra of 1-carbethoxymethyl-5,5-dimethyl-barbituric acid (34) in aqueous 5.305 $10^{-5}$ molar solutions at various $\mathrm{pH}$ are summarized in Fig. 6. In analogy with the above findings the following tautomeric equilibria might be operative:<smiles>CCOC(=O)N1C(=O)NC(=O)C(C)(C)C1=O</smiles>

XVIII<smiles>CCOC(=O)N1C(=O)C(C)(C)C(=O)N1[O-]</smiles>

XIX<smiles>CCOC(=O)N1C(=O)N(C)C(=O)C1(C)C</smiles>

$\mathrm{XX}$

In acid as well as in neutral solution, the keto-form XVIII is present giving an absorption peak at $2150 \AA$ with $\varepsilon_{\max }=6800$. The strong band at $2400 \AA$ $\left(\varepsilon_{\max }=6850\right)$ developing at $\mathrm{pH} 10.9$ will necessarily be due to the ion XIX. At pH 13, however, this derivative shows no selective absorption other than the usual end absorption. The conclusion to be drawn from this finding is that the structure $\mathrm{XX}$, as the sodium salt, does not cause the peak absorption common to all other higher homologues:

This interpretation seems to be substantiated by a comparative study of the three derivatives in Fig. 4-6, where the substituent groups in the 5,5position change from di-allyl via methyl-allyl to di-methyl.

All the compounds have a strong band at $\mathrm{pH}$. 10.9, which may be attributed to the ions XI, XVI, and XIX (including structures analogous to the configurations XIII and XIV) with an enolised structure. At pH 13, however, there is a progressive change in the spectrum for the three substances. For the diallyl derivative, the absorption intensity at $\mathrm{pH} 13$ is 96 per cent of that at $\mathrm{pH}$ 10.9. The corresponding figure for the methyl-allyl derivative is 40 per cent and finally for the di-methyl derivative only 19 per cent with no selective 


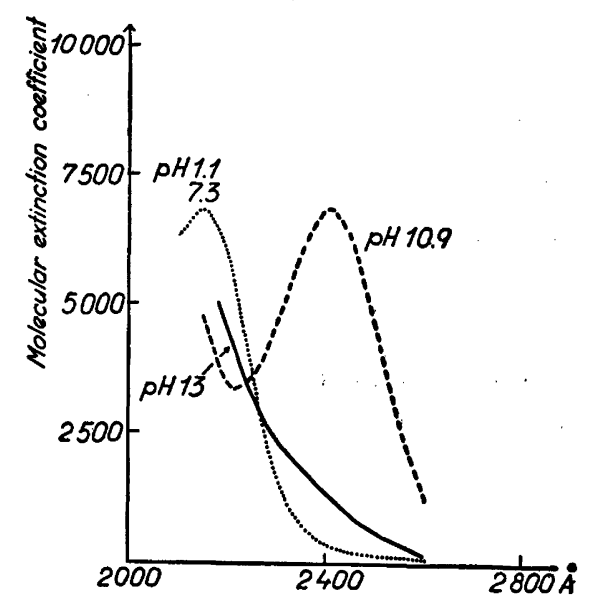

Fig. 6. Absorption spectra of $5.305 \cdot 10^{-5}$ molar aqueous solutions of 1-carbethoxy. methyl-5,5-dimethyl-barbituric acid at various $p H$ values.

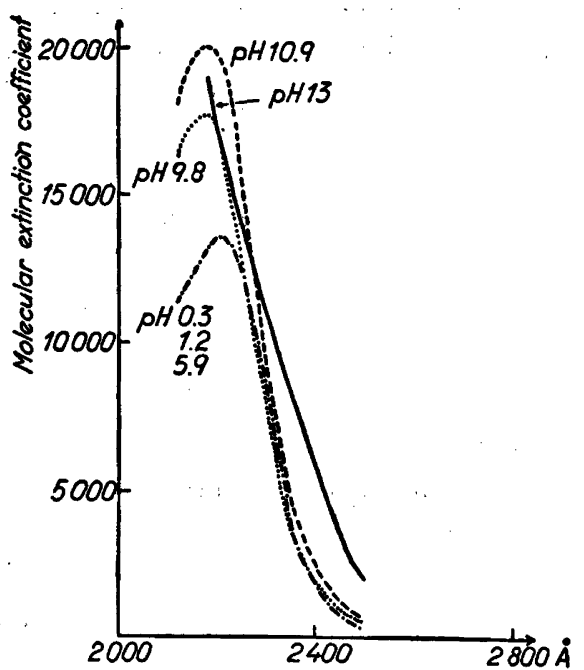

Fig. 7. Absorption spectra of $2.997 \cdot 10^{-5}$ molar aqueous solutions of 1,3-di (carbomethoxymethyl)-5,5-diallyl-barbituric acid at various $p H$.

absorption. This gradual decrease in ultra-violet absorption of the configurations XII, XVII, and XX might be referred to an effect of the decreasing molecular weight of the substituent alkyl groups in the 5,5-position.

It is of interest to note that Stuckey ${ }^{11}$ reported that 5,5-dimethyl-barbituric acid has an similiar absorption spectrum in that no peak is developed in $0.1 N$ sodium hydroxide solution. As an explanation of this phenomenon he states that the change from keto to enol ion does not take place. According to the forementioned results, however, this explanation cannot be correct.

The absorption spectra of $2.997 \cdot 10^{-5}$ molar aqueous solutions of 1,3-di (carbomethoxymethyl)-5,5-diallyl-barbituric acid (39) at varying $\mathrm{pH}$ values are shown in Fig. 7. In alkaline solution there is a strong band at $2180 \AA$ $\left(\varepsilon_{\max }=20200\right.$ at $\mathrm{pH} 10.9$ and $\varepsilon_{\max }=17800$ at $\left.\mathrm{pH} 9.8\right)$. In acid solution, the absorption is decreased so that $\varepsilon_{\max }=13600$ at $2210 \AA$. It should be noted that this peak corresponds to that shown in acid solution by the derivatives in Figs. 4-6, the addition of a carbomethoxymethyl group in the 3-position having the expected effect of weighting the molecule and causing a slight shift of the curve to longer wave-lengths. 
This substance is structurally incapable of undergoing tautomeric shifts. It must therefore exist predominantly in the following configuration:<smiles>CCCCCCC1(c2ccccc2)C(=O)N(CC(=O)OC)C(=O)N1CC(=O)O</smiles>

It will only be added that the absorption curves for derivative 38, 1,3-di(carbethoxymethyl)-5,5-diallyl-barbituric acid, are quite analogous to those shown in Fig. 7.

\section{SUMMARY}

A series of 1-carbethoxymethyl-5,5-dialkyl-barbituric acids and some of their $\mathrm{Na}$ and $\mathrm{K}$ salts have been prepared.

The alkaline hydrolysis and the stability of their solutions were studied. These barbiturates give no xanthyl derivative.

1,3-Di(carbomethoxymethyl)-5,5-diallyl-barbituric acid and its ethyl homologue have been synthesized.

The ultra-violet absorption spectra at varying $\mathrm{pH}$ for both types of barbiturates are reported.

\section{REFERENCES}

1. Rosén, O. Svensk Farm. Tidskr. 48 (1944) 497.

2. Schill, G. Svensk Farm. Tidskr. 49 (1945) 536.

3. Fischer, E., and Dilthey, A. Ber. 35 (1902) 854.

4. Fleischer, K., and Siefert, F. An. 422 (1921) 295.

5. Fabre, R. Bull. soc. chim. France 33 (1923) 781.

6. Jespersen, J. C., and Thoudahl-Larsen, K. Dansk Tidsskr. Farm. 8 (1934) 212.

7. Gad, I. Arch. exptl. Path. Pharmakol. 199 (1942) 449.

8. McCutcheon, R. S., and Plein, E. M. J. Am. Pharm. Ass. 38 (1949) 24.

9. Sandberg, F. Acta Physiol. Scand. 18 (1949) 204.

10. Fredholm, H. Die ultraviolett Absorption einiger Glieder der Barbitursäuregruppe in wässriger Lösung. Uppsala (1937) p. 24.

11. Stuckey, R. E. Quart. J. Pharm. Pharmacol. 15 (1942) 377. 


\title{
Some New Hydantoic Acid Derivatives
}

\author{
OLOV ROSEN
}

Department of Organic Chemistry, Kungl. Farmaceutiska Institutet, Stockholm, Sweden

$\mathbf{U}^{\mathrm{n}}$ reides of certain brominated monocarboxylic acids have been used in medicine owing to their sedative effect. Most important among these compounds are $\alpha$-bromo-isovaleryl-urea (bromyl, bromural) and bromodiethyl-acetyl-urea (carbromal, adalin), both of which are included in several modern pharmacopoeias. Barbituric acid, parent substance of the hitherto dominating group of synthetic hypnotics, is the ureide of the dicarboxylic malonic acid. Rosén and Sandberg ${ }^{1,2}(1944,1950)$ have shown that malonic acid, or a C-substituted malonic acid, and an ester of hydantoic acid can be converted under suitable conditions into barbituric acid derivatives:<smiles>[R10]OC(=O)NCC(N)=O</smiles>

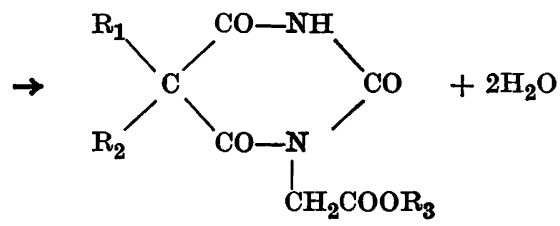

If $R_{1}$ and $R_{2}$ both are alkyl radicals, such as ethyl, allyl or phenyl, the reaction product is a hypnotic one, though weaker and of shorter duration of action than the corresponding substance without any substituent on the $\mathrm{N}$-atom. In this connection it would be of interest to synthesize analogous variants of the bromural-adalin-type and to test their sedative effect. For this reason $\alpha$-bromo-isovaleryl bromide and bromodiethyl-acetyl bromide respectively were brought into reaction with an ester of hydantoic acid:

$$
\begin{aligned}
&\left(\mathrm{CH}_{3}\right)_{2} \cdot \mathrm{CH} \cdot \mathrm{CHBr} \cdot \mathrm{COBr}+\mathrm{NH}_{2} \cdot \mathrm{CO} \cdot \mathrm{NH} \cdot \mathrm{CH}_{2} \cdot \mathrm{COOR} \rightarrow \\
& \rightarrow\left(\mathrm{CH}_{3}\right)_{2} \cdot \mathrm{CH} \cdot \mathrm{CHBr} \cdot \mathrm{CO} \cdot \mathrm{NH} \cdot \mathrm{CO} \cdot \mathrm{NH} \cdot \mathrm{CH}_{2} \cdot \mathrm{COOR}+\mathrm{HBr}, \\
&\left(\mathrm{C}_{2} \mathrm{H}_{5}\right)_{2} \cdot \mathrm{CBr} \cdot \mathrm{COBr}+\mathrm{NH}_{2} \cdot \mathrm{CO} \cdot \mathrm{NH} \cdot \mathrm{CH}_{2} \cdot \mathrm{COOR} \rightarrow \\
& \rightarrow\left(\mathrm{C}_{2} \mathrm{H}_{5}\right)_{2} \cdot \mathrm{CBr} \cdot \mathrm{CO} \cdot \mathrm{NH} \cdot \mathrm{CO} \cdot \mathrm{NH} \cdot \mathrm{CH}_{2} \cdot \mathrm{COOR}+\mathrm{HBr}
\end{aligned}
$$

